\title{
EFEKTIFITAS PENERAPAN ABSENSI FINGER PRINT TERHADAP DISIPLIN PEGAWAI DI KANTOR KECAMATAN SORAWOLIO KOTA BAUBAU
}

\author{
Anong Nani ${ }^{1}$, Andy Arya Maulana Wijaya ${ }^{2}$ \\ ${ }^{1}$ Mahasiswa Ilmu Pemerintahan \\ ${ }^{2}$ Dosen Ilmu Pemerintahan \\ Fakultas Ilmu Sosial dan Ilmu Politik \\ Universitas Muhammadiyah Buton
}

\begin{abstract}
Abstrak
Pemanfaatan Teknologi Informasi menjadi salah satu daya dukung dalam proses pemerintahan, khususnya dalam penerapan absensi finger print untuk mengawasi kehadiran pegawai. Teknologi ini juga digunakan pada Kantor Kecamatan Sorawolio Kota Baubau, namun dalam implementasinya dianggap belum berjalan efektif dan efisisen. Penelitian ini mengkaji dampak penerapan model absensi finger print dan sejumlah faktor yang memengaruhinya. Tujuan dari penelitian ini adalah untuk mengetahui dampak penerapan absensi finger print terhadap disiplin Pegawai Negeri Sipil di Kantor Kecamatan Sorawolio Kota Baubau. Metode yang digunakan dalam penelitian ini adalah metode deskriptif kualitatif. Data penelitian diperoleh melalui sejumlah Informan pegawai di Kantor Kecamatan Sorawolio. Pengumpulan data dilakukan dengan wawancara mendalam, studi dokumen dan observasi langsung oleh peneliti.

Hasil Penelitian ini menunjukkan bahwa penerapan absensi finger print pada pegawai Kantor Kecamatan Sorawolio cenderung meningkatkan disiplin terhadap kehadiran pegawai, dengan dukungan adanya data yang tercatat secara detail tentang ketepatan pegawai masuk maupun pulang kantor. Namun dalam penerapan teknologi absensi finger print ini, masih menemui beberapa kendala diantaranya keterlambatan jam masuk pegawai serta aksesibilitas pegawai jika berkaitan dengan tempat tinggal dan lokasi kegiatan. Sehingga masih sering ditemui adanya pegawai yang sering datang terlambat maupun pulang yang lebih cepat dari jadwal. Diharapkan melalui hasil kajian ini menjadi bahan koordinasi Camat Sorawolio dengan Pemerintah Kota Baubau untuk dilakukan perbaikan aturan dan sistem kerjanya terhadap pemantauan kedisiplinan pegawai di Kota Baubau.
\end{abstract}

Kata Kunci : disiplin, finger print, Pegawai Negeri 


\section{Pendahuluan}

Perkembangan teknologi di era globalisasi yang semakin hari semakin canggih sehingga mempermudah semua kalangan untuk mengakses informasi. Perkembangan tersebut bukan hanya melahirkan era informasi global melainkan melahirkan media informasi dan telekomunikasi yang tidak mengenal waktu maupun tempat. Perkembangan teknologi yang semakin canggih sangat dirasakan di berbagai bidang, termasuk pada bidang ekonomi dan manajemen yang semakin hari membawa kebaikan. Hal ini dibuktikan dengan munculnya alat-alat elektronik yang serba canggih dalam kehidupan masyarakat, dan memudahkan para pegawai dalam mengakses informasi maupun mengolah data. Dengan perkembangan alat informasi yang canggih itu mempermudah pekerjaan kantor sehingga produktivitas kerja kantor semakin tinggi.

Banyak alat canggih yang di pakai dalam sebuah kantor namun salah satu dari alat canggih tersebut yaitu penerapan Absensi Automatic Finger print Identification System (AFIS). Absensi Automatic Finger print Identification System adalah sebuah alat yang sangat membantu pegawai kantor dalam hal system Absensi. Karena Pegawai tinggal menempelkan jari yang telah di program di mesin Finger print, mesin dapat merekam ketepatan waktu kehadiran dan ketepatan jam pulang pegawai dikantor. Kegiatan pencatatan kehadiran Pegawai dikantor akan sangat berpengaruh terhadap pekerjaan kantor, pengaruhnya tersebut tentunya berhubungan langsung dengan semangat kerja dan disiplin kerja pegawai di Kantor Kecamatan Sorawolio Kota Baubau.

Faktor yang sangat penting untuk mencapai semangat kerja yang tinggi adalah pelaksanaan disiplin kerja dari para pegawai, karena hal tersebut merupakan salah satu faktor penentu untuk menunjang kinerja seorang pegawai didalam instansinya. Karena kedisiplinan adalah kesadaran dalam kesediaan seseorang menaati semua peraturan dan norma-norma sosial yang berlaku. Dengan adanya kesadaran dalam melaksanakan aturan-aturan dalam instansi yang diwujudkan dalam disiplin yang tinggi, maka suatu produktivitas kerja juga akan baik.

Penerapan absensi finger print adalah untuk meningkatkan kedisiplinan terhadap kehadiran pegawai di Kantor Kecamatan Sorawolio, disamping itu tujuan utamanya adalah untuk memudahkan pengontrolan dan otomatisasi sistem.

Menurut Singodimedjo (dalam Edy Sutrisno 2010:86), bahwa kedisiplinan adalah sikap kesediaan dan kerelaan seseorang untuk mematuhi dan menaati normanorma peraturan yang berlaku di sekitarnya. Disiplin karyawan atau pegawai yang baik akan mempercepat tujuan perusahaan, sedangkan disiplin yang merosot akan menjadi penghalang dan memperlambat pencapaian tujuan perusahaan

Dalam rangka meningkatkan kedisiplinan pegawai pada instansi Pemerintah menuju kearah profesionalisme dan menunjang terciptanya pemerintahan yang baik, perlu adanya penyatuan arah dan pandangan bagi pegawai pemerintah yang dapat dipergunakan sebagai pedoman atau acuan dalam melaksanakan tugas baik manajerial maupun operasional diseluruh bidang tugas dan unit organisasi instansi pemerintah secara terpadu. 
Saat belum diterapkannya absensi finger print di Kantor Kecamatan Sorawolio dan masih menggunakan absensi manual, sangat sulit dalam mengontrol kehadiran Pegawai Negeri Sipil khususnya masuk kantor dan pulang kantor, begitupula dalam penegakan disiplin pegawai tidak maksimal. Karena sering terjadinya titip menitip absen antar pegawai sangat besar, bahkan Pegawai selalu merapel paraf pada absen, sehingga sering dijumpai ada Pegawai Negeri Sipil yang belum berada di Kantor pada saat apel Pagi maupun pada apel pulang, seperti halnya yang ditetapkan melalui Keputusan Presiden Nomor 68 Tahun 1995 Tentang Hari Kerja di Lingkungan Pemerintah, yakni dalam 1 minggu jumlah hari kerja Pegawai Negeri Sipil 37, 5 Jam kerja.

Karena dengan absensi finger print (sidik jari) yang merupakan sebuah mesin dengan bantuan software untuk mengisi data kehadiran komunitas, kelompok maupun instansi yang menggunakannya. Dengan menggunakan alat ini, absensi yang direkapitulasi setiap sebulan sekali akan dapat dengan mudah diketahui pelanggaran jam kerja maupun keterlambatan yang telah dilakukan oleh para pegawai, dikarenakan pada absensi elektronik ini sulit dilakukan manipulasi data.

Peraturan Pemerintah Nomor 53 Tahun 2010 tentang Disiplin Pegawai Negeri Sipil merupakan tonggak aturan penerapan kedisiplinan bagi seluruh pegawai negeri dalam lingkup Negara Kesatuan Republik Indonesia. Agar tercipta tata pemerintahan yang bersih dan berwibawa, tentu diperlukan disiplin para pejabat dan administrasi kepegawaian (Darmayanti \& Mukti, 2017).

Disisi lain, berdasarkan Surat Menteri PANRB No B/2338/M.PANRB/06/2016 Tanggal 27 Juni 2016 tentang Penggunaan Absensi Berbasis Elektronik di Lingkungan Instansi Pemerintah, menyebutkan "Mengoptimalkan penggunaan sistem absensi berbasis elektronik guna menghindari adanya kecurangan dan/atau manipulasi data yang berhubungan dengan kehadiran pegawai."

Sehingga pada bulan Januari 2018 Kantor Kecamatan Sorawolio menerapkan Absensi Finger print, setelah diterapkannya absensi berbasis elektronik tersebut dapat merubah secara signifikan terhadap kedisiplinan pegawai dalam hal ini jam masuk dan jam pulang kantor. Sehingga absensi finger print dapat dijadikan sebagai alat control bagi pimpinan untuk melihat tingkat kedisiplinan pegawai Kantor Kecamatan Sorawolio. Penelitian ini dilakukan melalui analisa penerapan Absensi Finger Print yang telah dilakukan pada rentang waktu dari bulan Januari s/d April 2019, dan kemudian dihubungkan terhadap peningkatan kehadiran sebagai bagian dari kedisiplinan pegawai pada tanggal dan waktu sebelum diterapkannya absensi finger print tersebut. 


\section{Metode Penelitian}

Jenis penelitian ini menggunakan Penelitian deskriptif kualitatif. Dalam menentukan sampel digunakan teknik purposive sampling, sehingga informan dalam penelitian ini adalah meliputi informan yang mengetahui perihal kebijakan, implementasi dan pengawasan absensi finger print serta dokumentasi absensi pegawai sebelum diterapkannya absen finger print. Kemudian data diperoleh melalaui Observasi langsung pada lokasi penelitian, wawancara mendalam, dan telaah dokumen relevan dengan tujuan penelitian. Teknik analisa data menggunakan analisis kualitatif, untuk memberikan deskripsi terhadap gejala sosial yang ditemukan dalam penelitian.

\section{Hasil Penelitian dan Pembahasan}

\section{a. Kantor Kecamatan Sorawolio dan Penerapan Absen Finger Print.}

Kecamatan Sorawolio adalah salah satu pecahan pemekaran dari Kecamatan Wolio dibentuk pada tanggal 27 Juli 1982 yang bertepatan dengan Pembentukan Kota Administratif Baubau, yang meliputi 3 desa dan pada tahun 1996 terbentuk pemekaran Desa Karya Baru menjadi Desa Bugi sehingga berjumlah 4 Desa, dan saat ini telah berubah status seluruhnya dari Desa menjadi Kelurahan, yaitu: Kelurahan Kaisabu Baru, Kelurahan Karya Baru, Kelurahan Bugi dan Kelurahan Gonda Baru.

Penerapan teknologi finger print mulai digunakan pada bulan Januari 2018 Kantor Kecamatan Sorawolio Kota Baubau. Tujuan utama pelaksanaan ini adalah untuk merubah proses dan pengawasan kehadiran pegawai di kantor kecamatan Sorawolio. Mekipun belum secara signifikan memberikan dampak positif bagi stimulus terhadap pola kedisiplinan, namun hal ini mampu menjadi sarana pengawasan kedisiplinan bagi pimpinan terhadap kedisiplinan pegawainya. Sehingga absensi finger print dapat dijadikan sebagai alat control bagi pimpinan untuk melihat tingkat kedisiplinan pegawai Kantor Kecamatan Sorawolio.

Kantor kecamatan sorawolio telah menerapkan absensi finger print sejak januari 2018 dan sebelumnya masih menggunakan absensi manual. Sehingga pegawai kecamatan sorawolio diwajibkan untuk masuk tepat waktu dan pulang juga harus tepat waktu. Karena di mesin absensi finger print telah dibuat program masuk jam 07.30 pulang jam 16.00 untuk hari senin sampai Kamis dan masuk jam 07.30 pulang jam 17.00 untuk hari jum'at. Dengan berubahnya sistim pencatatan kehadiran pegawai dari sistim manual ke sistim elektronik pegawai dituntut untuk mampu beradaptasi, dan mematuhi segala bentuk ketentuan yang berkaitan dengan absensi kehadiran pegawai.

\section{b. Efektifitas Penerapan Absensi Finger Print di Kantor Kecamatan Sorawolio.}

Dalam pasal 3 ayat (11) Peraturan Pemerintah Republik Indonesia Nomor 53 Tahun 2010 menyatakan bahwa Setiap Pegawai Negeri Sipil berkewajiban untuk masuk kerja dan menaati ketentuan jam kerja. Jam kerja yang telah diatur yaitu Hari Senin sampai dengan Kamis masuk jam 07.30 dan pulang jam 16.00 begitu pula hari Jumat 
masuk jam 07.30 pulang jam 17.00. Para Pegawai Kecamatan Sorawolio sudah patut pada ketentuan jam kerja tersebut. Bila ditemui ada pegawai yang tidak melakukan finger pada saat jam masuk maupun pulang dengan tepat waktu karena adanya tugas untuk mewakili pimpinan dalam mengikuti rapat, sedangkan jarak antara Kantor Kecamatan Sorawolio dengan letak tempat tinggal sangat jauh, sehingga dijumpai pada mesin absensi finger print terjadi keterlambatan masuk kantor maupun cepat pulang dari kantor.

Namun dalam implementasinya ditemukan beberapa faktor yang turut memengaruhi penerapan absensi finger print di kecamatan sorawolio. Dimana, pada akhir bulan setelah dilakukan evaluasi terhadap jumlah kehadiran pegawai selama 1 bulan ditemukan adanya data bahwa keterlambatan pegawai masuk kantor sesuai jadwal menjadi dominan. Hanya saja keterlambatan tersebut jika diakumulasi dan dikaitkan dengan aturan pemotongan tunjangan, hasinya tidak begitu berpengaruh dimana akumulasi keterlambatan hanya mencapai 7.5 jam, dan hal tersebut tidak berpengaruh pada pemberian tunjangan pegawai.

Disisi lain, penelitian ini menemukan bahwa penerapan Absensi finger print di Kantor Kecamatan sorawolio telah mengarah pada tujuan organisasi yaitu meningkatkan kehadiran pegawai, jarak antara tempat kerja dengan rumah Pegawai Kecamatan Sorawolio tidak menjadi permasalahan. Mereka tetap aktif masuk kantor setiap harinya sesuai ketentuan yang ada, dengan demikian pencapaian target dalam penerapan absensi finger print dapat terlaksana.

Mencermati deskripsi tersebut dapat dikatakan bahwa penerapan Absensi finger print pada Kantor Kecamatan Sorawolio, memberikan stimulus bagi tingkat kehadiran pegawai sesuai target yang ditetapkan. Hal ini, bisa menjelaskan bahwa absensi finger print sekalipun masih sangat minimal turut memberi pengaruh pada tingkatan habituasi (kebiasaan) kehadiran Pegawai, sehingga pada sisi ini tujuan organisasi dapat tercapai sesuai target yang telah direncanakan.

Selain itu, adanya perubahan sikap ini diketahui juga bahwa turut dipengaruhi bahwa adanya reward Pemberian Tunjangan Perbaikan Penghasilan bagi Pegawai yang aktif masuk dan pulang Kantor sesuai waktu yang telah ditentukan. Dengan adanya alat absensi finger print sangatlah membantu dalam mengakumulasi kehadiran pegawai dalam satu bulan, melalui mekanisme download data hal ini menjadi lebih mudah.

Dalam hal kinerja, penarapan absensi finger print memungkinkan adanya kinerja pegawai pada Kantor Kecamatan Sorawolio meningkat. Tentu, hal ini dapat dilihat dari disiplin kerja, pegawai datang tepat waktu dan pulang dari kantor tepat waktu. Termotivasinya pegawai tersebut diiringi dengan adanya reward dari pemerintah Kota Baubau tentang pemberian tunjangan perbaikan penghasilan bagi pegawai yang disiplin, sehingga pelayanan terhadap publik dapat terlaksana dengan baik. 
Tabel 1

Daftar Rekapitulasi Kehadiran Pegawai Kecamatan Sorawolio

Bulan Januari s/d April 2019

\begin{tabular}{|c|c|c|c|c|c|c|}
\hline \multirow[b]{2}{*}{ Nama } & \multicolumn{4}{|c|}{ Realisasi Jam Kerja Pegawai ASN } & \multirow{2}{*}{$\begin{array}{c}\text { Rata-Rata } \\
\text { Kehadiran } \\
\text { / Bulan }\end{array}$} & \multirow{2}{*}{$\begin{array}{c}\text { Selisih Realisasi } \\
\text { Jam Kerja dan } \\
\text { Jam Kerja } \\
\text { Sesuai Aturan } \\
\text { Berlaku (150 } \\
\text { Jam/ Bulan) }\end{array}$} \\
\hline & Januari & Februari & Maret & April & & \\
\hline La Samiri Saboku, SH & 150 & 150 & 150 & 149,8 & 150 & 0 \\
\hline Arif Indrawan, SE & 149,5 & 150 & 146 & 149 & 149 & 1 \\
\hline La Juba, S.Sos & 150 & 148,5 & 150 & 146,5 & 149 & 1 \\
\hline Maliyhu & 150 & 150 & 149,8 & 150 & 150 & 0 \\
\hline Zuliati & 150 & 149,5 & 147 & 149,5 & 149 & 1 \\
\hline Tahir Gade, S.IP & 150 & 147 & 145 & 149 & 148 & 2 \\
\hline Sutiarni, S.IP & 150 & 149 & 149 & 150 & 150 & 1 \\
\hline Dasuki, S.IP & 149,8 & 148 & 149 & 150 & 149 & 1 \\
\hline Anong Nani & 150 & 150 & 150 & 150 & 150 & 0 \\
\hline \multirow[t]{2}{*}{ Nurmin } & 150 & 149 & 149 & 150 & 150 & 1 \\
\hline & & & \multicolumn{2}{|c|}{ Rata-Rata } & 149 & 1 \\
\hline & & \multicolumn{4}{|c|}{ Akumulasi Keterlambatan Jam Kerja (Jam) } & 0,7775 \\
\hline
\end{tabular}

(Sumber: Analisis Hasil Download Data Finger Print Pegawai Kantor Kecamatan Sorawolio, Juli 2019)

Berdasarkan data pada tabel 1 , diperoleh data bahwa terjadi fluktuasi kehadiran pegawai sekalipun tidak begitu signifikan dalam kuatitasnya setiap bulannya. Hal tersebut tergambar dalam data bahwa akumulasi dalam satu bulan jam kerja pegawai adalah 150 jam, sedangkan rata-rat jam kerja oleh pegawai kantor kecamatan sorawolio adalah 149 jam, hanya selisih 1 jam keterlambatan. Sekalipun menurut aturan dalam pasal 8 ayat (1) Permenkumham No. 33/2017 yakni keterlembatan selama 30 menit, maka pegawai yang bersangkutan wajib mengganti waktu keterlambatan selama 30 (tiga puluh) menit pada hari yang sama. Namun pada kantor kecamatan sorawolio, hal ini belum dilakukan sehingga masih hanya sebatas data-data kedisiplinan pegawai saja. Mencermati kondisi tersebut, kajian ini memperoleh gambaran bahwa sejatinya penerapan absensi (fingerprint) memiliki pengaruh dalam meningkatkan disiplin kerja pegawai, sekalipun belum memenuhi akumulasi kewajiban jam kerja dalam satu bulan seperti yang diatur dalam Keputusan Presiden Nomor 68 Tahun 1995 tentang Hari Kerja di Lingkungan Lembaga Pemerintah.

Untuk itu, kajian dalam penelitian ini menjelaskan bahwa dampak dari penerapan absensi finger print di Kantor Kecamatan Sorawolio dapat meningkatkan 
disiplin kerja pegawai. Namun respon Pegawai terhadap penerapan finger print ini beragam diantaranya kesesuaian waktu dan tempat tinggal Pegawai yang membuat adanya keterlambatan dalam melakukan absen. Sehingga penerapan finger print ini menurut kajian peneliti perlu tinjau yang dilakukan dengan terus memperbaiki sistim dan aturannya.

\section{Kesimpulan}

Berdasarkan deskripsi hasil dan pembahasan dalam kajian ini, maka dapat disimpulkan bahwa Penerapan absensi finger print pada pegawai Kantor Kecamatan Sorawolio hingga saat ini dapat memberikan pengaruh pada peningkatan disiplin terhadap jadwal kehadiran pegawai. Hal ini didukung oleh adanya reward dan punishment yang diberikan bagi yang mentaati dan melanggar ketentuan jadwal yang telah disepakati sebelumnya. Hanya saja, peneliti mengamati bahwa meski masih terdapat adanya keterlambatan jam masuk pegawai seperti yang tercatat pada data absen finger print, sekalipun belum ikut memengaruhi terhadap pemotongan tunjangan pegawai. Namun hal ini dapat menjadi bahan evaluasi pimpinan dalam hal ini camat, guna adanya perubahan perilaku terhadap kedisiplinan pegawai, sehingga mampu memberikan kinerja yang optimal dan layanan publik yang maksimal di kantor kecamatan sorawolio Kota Baubau. Selain itu, perbaikan teknis berupa system dan sumber daya juga perlu dilakukan dalam penerapan absensi finger print tersebut.

\section{Referensi}

Arikunto, Suharsimi, 2010. Prosedur Penelitian Suatu Pendekatan Praktif Edisi Revisi. Pt Rieneka Cipta, Jakarta

Asmiarsih, Tety. 2006. Pengaruh Pengawasan Terhadap Disiplin Kerja Pegawai Kantor Badan Kepegawaian Daerah Brebes, Skripsi, Fakultas Ilmu Sosial Universitas Semarang

Damayanti, D., \& Mukti, H. (2017). PELAKSANAAN DISIPLIN PEGAWAI BERDASARKAN PERATURAN PEMERINTAH PEMERINTAH NOMOR 53 TAHUN 2010 TENTANG DISIPLIN PEGAWAI NEGERI SIPIL PADA KEJAKSAAN TINGGI KALIMANTAN TIMUR (Studi Kantor Kejaksaan Tinggi Kalimantan Timur). Yuriska: Jurnal Ilmiah Hukum, 8(1), 46-58.

Darsono Dan Tjatjuk, Siswandoko, 2011, Manajemen Sumber Daya Manusia Abad 21, Nusantara Consulting, Jakarta

Efektivitas, D. (2016). Efektivitas Pemasangan Absen Sidik Jari (Finger Scan) Dalam Meningkatkan Disiplin Kerja Pegawai Rektorat Universitas Mulawarman Samarinda.Sari, P. P. (2016). Peranan Disiplin Kerja Terhadap Kinerja Karyawan Bagian Umum Sekretariat Daerah Kantor Walikota Medan.

Gazali Sina Muhammad, Efektivitas Pemasangan Absen Sidik Jari (Finger Scan) dalam Meningkatkan Disiplin Kerja Pegawai Rektorat Universitas Mulawarman Samarinda, (eJurnal Ilmu Pemerintahan, Volume 4, Nomor 1, 2016), 
Hariadi, P. S. L. (2018). Efektivitas Penerapan Absensi Fingerprint dan Sanksi Dalam Meningkatkan Disiplin Kerja Karyawan Kantor PT. Rimba Perkasa Utama Samarinda. Jurnal (Online) Administrasi Bisnis ISSN, 2355-5408.

Hartatik, Indah., Buku Praktis Mengembangankan SDM, Yogyakarta : Laksana, 2014

Junaidi, J., Anugrah, L., \& Pancasakti, A. D. (2015). Model Aplikasi Monitoring Sistem Absensi Sidik Jari Sebagai Pendukung Keputusan Untuk Penilaian Kinerja Pegawai. Proceedings Konferensi Nasional Sistem dan Informatika (KNS\&I).

Kari, A. (2013). The Effect of Job Satisfaction and Motivation on Employee Engagement of Administrative Staff of Bandung State Polytechnic. JURNAL ILMU MANAJEMEN DAN BISNIS, 5(1).Mangkunegara A.A, Manajemen Sumber Daya Manusia Perusahaan, (Bandung : PT Remaja Rosdakarya, 2004)

Lestari, A. W., \& Firdausi, F. (2016). Pelaksanaan Sistem Reward dan Punishment di Lingkungan Kementerian Keuangan dalam Upaya Meningkatkan Kedisiplinan Pegawai (Studi Pada Kantor Pelayanan Perbendaharaan Negara/KPPN, Kudus). REFORMASI, 6(1).

Maeyasari, E., Widyastuti, Y., \& Yulianti, R. (2012). Pengaruh Efektivitas Penerapan Absensi Finger Print Terhadap Disiplin Pegawai Negeri Sipil Di Sekretariat Daerah Kabupaten Lebak (Doctoral dissertation, Universitas Sultan Ageng Tirtayasa).

Mangkunegara, A.A (2013) Manajemen Sumber Daya Manusia. Cetakan Kesebelas, Bandung: PT. Remaja Rosdakarya

Moleong, Lexy J, 2014, Metodologi Penelitian Kualitatif, PT Remaja Rosdakarya, Bandung.

Peraturan Pemerintah Nomor 53 Tahun 2010 Tentang Disiplin Pegawai Negeri Sipil

Peraturan Menteri Dalam Negeri Republik Indonesia Nomor 4 Tahun 2013

Ramadhona, M., \& Sahuri, C. (2017). Efektivitas Disiplin Pegawai di Sekertariat Daerah Kota Pekanbaru. Jurnal Online Mahasiswa Fakultas Ilmu Sosial dan Ilmu Politik Universitas Riau, 4(1), 1-14.

Sondang P. Siagian, Manajemen Sumber Daya Manusia, (Jakarta : Bumi Aksara, 2014), Sugiyono. 2011. Metode Penelitian Kuantitatif, Kualitatif dan R\&D. Bandung: Afabeta

Surat Menteri PANRB No B/2338/M.PANRB/06/2016 Tanggal 27 Juni 2016 tentang Penggunaan Absensi Berbasis Elektronik di Lingkungan Instansi Pemerintah Susanto, Ahmad., Manajemen Peningkatan Kinerja Guru : Konsep, Strategi dan Implementasinya, Ed. I, Jakarta : Prenadamedia Group, 2016

Tangkilisan, Hessel Nogi S. 2005. Manajemen Publik. Jakarta: Gramedia Widia Sarana Indonesia. 